\title{
A Systematic Review for The Implementation of Risk Management Within Construction of Mega Housing Projects
}

\author{
Mohamed Nabawy, Charles Egbu \\ London South Bank University, School of the Built Environment and Architecture, UK
}

Maged Morcos

British University in Egypt, Construction Engineering and Management Program, Egypt

Contact: MohamedAhmedNabawy85@yahoo.com

\begin{abstract}
Recent years have seen an increase in the number of Mega housing Projects around the world. This increase was to cater for increased population growth, increased urbanisation, scarcity of land, and due to changes in the way we work and live. This trend is likely to continue for a while. Mega housing projects are characterized by their high construction budget, complexity, and their benefits to the society. Mega housing projects, however, raise a number of different challenges and complexities, which need consideration in order to successfully deliver them within cost, time and specified quality parameters. The paper addresses the main construction challenges and opportunities of mega housing projects. Furthermore, consideration is given to the human resources (HR) challenges and opportunities, as well as the efficiency of risk management processes throughout the construction of mega housing projects. Different Case studies are analysed, and a risk register for the successful delivery of mega housing projects in construction is proffered. Conclusions for the benefit of contractors, policymakers, and academics are documented, together with selected recommendations around "value-add" from effective risk management of new mega housing projects.
\end{abstract}

Keywords: Mega Housing Projects, Challenges, Opportunities, Risk Register, Project Management, Construction, Construction Success.

\section{Introduction}

The total global megaproject spending is said to be USD 6-9 trillion annually, or 8 percent of total global GDP, which denotes the biggest investment boom in human history [1]. Mega housing projects are defined as a large-scale investment project, typically costing more than EUR 0.5 billion with colossal use of resources including money, human, and equipment's [2]. The construction of mega housing projects is considered to be one of the major poles and targets of countries because of social benefit return on their economies. Despite gained opportunities, challenges become more and more complex due to their complex scale and surrounding construction environment. The length of time required for project development and anchoring increased the projects' exposure to emergent risk. Each project encountered an average of four unforeseen and potentially catastrophic events during their long-life cycles [3]. Catastrophic consequences can be the result 
of failing in identifying and managing the challenges in the construction of mega housing projects. Failure to deliver a mega-project on time, within budget, or in accordance with regulatory or environmental requirements can have major repercussions on an organization's reputation and revenue performance [4].

\section{Methodology}

Challenges and opportunities in construction can present a large list of risk factors which can impact mega housing project's schedule, budget, and quality delivered. Risk management process is important in managing Importance in Construction of Mega housing Projects [3]. The paper aims to identify mega housing projects construction challenges and opportunities which leads to successful delivery of mega housing projects. The methodology of this paper is explained in Figure 1 below, which shows the process of research methodology used in identifying mega housing projects challenges and opportunities towards the successful construction of mega housing projects. First, complexities in the construction of Mega housing projects are reviewed. Thus, detecting the reasons for high complexity in construction of mega housing projects. Mega housing projects case studies are then reviewed by which projects constructed in developed and developing countries are explored in detail.

Furthermore, both challenges and opportunities for several worldwide mega housing projects are recognized and classified. To best link mega housing projects challenges with risks, risk management researchers are further explored. Studies, Construction risks and categories can be realized. Identified risk factors are then categorized towards both internal and external stakeholder's project environment. Mega housing projects construction challenges and opportunities are then linked with risk management studies to highlight the most important challenges recognized by the researchers. Failure and success in construction delivery of mega housing projects are then analysed through a review of case studies results. By the end of this paper, lessons and recommendations regarding projects and researchers on mega housing projects and risk management are reviewed and analysed.

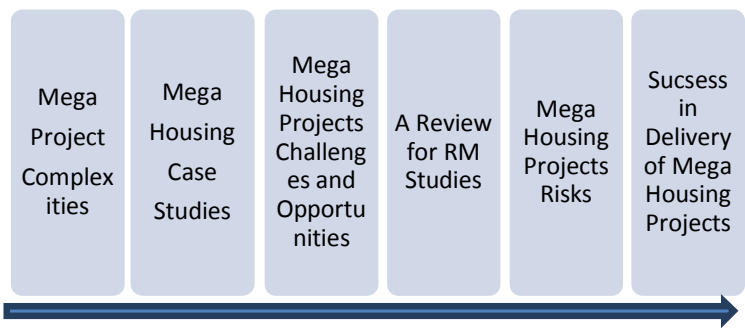

Figure 1 The Process of the Research Methodology.

\section{A Review for Complexities in Construction of Mega Projects}

Mega housing projects are characterised by their increase in construction challenges complexity. Mega housing projects also last for a long period of time which requires accurate management of larger degree of inheriting uncertainties. Mega projects are set to be more complex due to their involvement of high level of risk and uncertainty, a high number of people conflicts, missing rise of interpretation, large number of resources managed between stakeholder's, and long-life implementation [2]. It is important to maintain a proactive communication between stakeholders working on the construction of mega projects [5]. Megaprojects complexity is defined as a property of mega-project construction which makes it difficult to understand and control [6]. Table1 below includes a further review for authors opinions about mega housing projects description of complexity.

Table 1. Complexity in Construction of Mega housing projects

\begin{tabular}{ccl}
\hline Author & Year & $\begin{array}{c}\text { Mega housing projects } \\
\text { Complexity Highlights }\end{array}$ \\
\hline Liu et al & 2014 & $\begin{array}{l}\text { Strategies for high- } \\
\text { performance communication } \\
\text { to be added [5] }\end{array}$ \\
\hline $\begin{array}{c}\text { Kardes et } \\
\text { al }\end{array}$ & 2013 & $\begin{array}{l}\text { High level of risk and } \\
\text { uncertainty, High number of } \\
\text { people conflicts, large number } \\
\text { of resources [2] }\end{array}$ \\
\hline Giezen & 2012 & $\begin{array}{l}\text { Reduction of mega projects } \\
\text { complexity for mega }\end{array}$ \\
\hline
\end{tabular}




\begin{tabular}{ccl}
\hline & & infrastructure projects [7] \\
\hline Vidal et al & 2011 & $\begin{array}{l}\text { As a property of a mega } \\
\text { project which makes it difficult } \\
\text { to understand and control [6] }\end{array}$ \\
\hline $\begin{array}{c}\text { Bosch } \\
\text { Rekveldt } \\
\text { et al }\end{array}$ & 2011 & $\begin{array}{l}\text { Technology, organization, } \\
\text { environmental framework to } \\
\text { assess complexity [8] }\end{array}$ \\
\hline Azim & 2010 & $\begin{array}{l}\text { Requires engaging the use of } \\
\text { more innovative technics [9] }\end{array}$ \\
\hline $\begin{array}{c}\text { Marrewijk } \\
\text { et al }\end{array}$ & 2008 & $\begin{array}{l}\text { Factors which lead to increase } \\
\text { in complexity as large scale, } \\
\text { long time, technology [10] }\end{array}$ \\
\hline $\begin{array}{c}\text { Bruijn \& } \\
\text { Leijten }\end{array}$ & 2008 & $\begin{array}{l}\text { Technical relative to larger } \\
\text { size, \& social relative to } \\
\text { communication of } \\
\text { stakeholder's [11] }\end{array}$ \\
\hline
\end{tabular}

Based on the review of construction complexities, it was revealed that the long schedule, the technology, communication, and coordination of different mega project parties are the basic elements of complexity. Most authors agreed on introducing more innovative management techniques to identify and manage the increase in uncertainties. Authors were worried about changes that could occur to a mega project due to its long-lasting project nature. Changes due to market, politics, and owner requirement could involve more risks towards the mega housing projects activities. In addition to that, most of the researchers also criticized the importance of collaboration and communication between mega housing projects stakeholders to manage mega housing projects complexities more smoothly and accurately.

\section{Mega Housing Projects Case Studies}

Table 2 presents different mega housing projects in different disciplines of civil engineering projects. All the projects share the same objective to serve a wide range of the population. This could be achieved by construction of different mega infrastructure projects and mega housing projects. The review aims at recognising construction of mega housing projects key Opportunities and Challenges. Different countries have been taken from different contexts in order to be able to highlight both challenges and opportunities in more details. Case Studies selected is to present countries from both developing and developed countries. Mega housing projects illustrated includes the Battersea Power Station development in London (England), Shibuya Station Area Redevelopment in Tokyo (Japan), Nanhui New City in China, New Capital City in Egypt, Mega housing projects in Capetown, and Leeuwpoort housing project in Boksburg, City of Wien mega project, China Yinchuan City megaproject, Smart City of Atalanta, developing mega housing projects in Dubai, City of Catalonia, and Smart City of Toronto mega project.

Table 2. Future Examples of Mega housing projects

\begin{tabular}{|c|c|c|c|}
\hline Author & Project & Country & Description \\
\hline $\begin{array}{l}\text { Sesant } \\
(2017)\end{array}$ & $\begin{array}{c}\text { Mega } \\
\text { Housing } \\
\text { Project in } \\
\text { Capetown }\end{array}$ & $\begin{array}{l}\text { Cape } \\
\text { town }\end{array}$ & $\begin{array}{l}\text { House } 11000 \\
\text { residents } \\
\text { Completion in } \\
2024 \text { [12] }\end{array}$ \\
\hline $\begin{array}{l}\text { Megan } \\
(2017)\end{array}$ & $\begin{array}{c}\text { Leeuwpoo } \\
\text { rt Mega } \\
\text { Housing } \\
\text { Project }\end{array}$ & Boksburg & $\begin{array}{l}19,000 \text { Houses. } \\
\text { For the middle- } \\
\text { income. [13] }\end{array}$ \\
\hline \multirow[t]{2}{*}{$\begin{array}{l}\text { Leann } \\
\text { Garfiel } \\
\quad d \\
(2017)\end{array}$} & $\begin{array}{l}\text { Shibuya } \\
\text { Station } \\
\text { Developm } \\
\text { ent project }\end{array}$ & $\begin{array}{l}\text { Tokyo } \\
\text { Japan }\end{array}$ & $\begin{array}{l}\text { Tokyo } 2020 \\
\text { Olympics } \\
\text { demands a } 50 \% \\
\text { increase in } \\
\text { housing14] }\end{array}$ \\
\hline & $\begin{array}{c}\text { Nanhui } \\
\text { New Mega } \\
\text { City } \\
\end{array}$ & China & $\begin{array}{l}800,000 \text { residen } \\
\text { ts with a cost of } \\
\$ 4.5 \text { billion [14] }\end{array}$ \\
\hline $\begin{array}{l}\text { Khorsh } \\
\text { ed } \\
(2017)\end{array}$ & $\begin{array}{c}\text { Egypt New } \\
\text { Capital } \\
\text { Mega } \\
\text { Project }\end{array}$ & Egypt & $\begin{array}{l}\text { Egypt New } \\
\text { Capital City. } \\
\text { Five million } \\
\text { people at a cost } \\
\text { of } \$ 45 \text { billion } \\
{[15]}\end{array}$ \\
\hline $\begin{array}{l}\text { Helfert, } \\
(2015)\end{array}$ & $\begin{array}{c}\text { Building } \\
\text { New Smart } \\
\text { Mega } \\
\text { Cities }\end{array}$ & $\begin{array}{l}\text { Mediterr } \\
\text { anean } \\
\text { Region }\end{array}$ & $\begin{array}{l}\text { ASCIMER is a 3- } \\
\text { year Research } \\
\text { uses Europe } \\
\text { Experience [16] }\end{array}$ \\
\hline $\begin{array}{c}\text { Ina } \\
(2016)\end{array}$ & $\begin{array}{c}\text { Smart City } \\
\text { of Wien } \\
\text { Housing } \\
\text { Project }\end{array}$ & Vienna & $\begin{array}{l}\text { The big Smart } \\
\text { City Wien } \\
\text { launched in } \\
\text { 2011. [17] }\end{array}$ \\
\hline $\begin{array}{l}\text { Ning et } \\
\text { al. } \\
(2016)\end{array}$ & $\begin{array}{l}\text { Smart City } \\
\text { of Toronto }\end{array}$ & Toronto & $\begin{array}{l}25 \text { years and } \\
\$ 34 \text { billion } \\
\text { required to } \\
\text { transform into } \\
\text { sustainable } \\
\text { communities } \\
{[18]}\end{array}$ \\
\hline
\end{tabular}




\section{Challenges and Opportunities in Construction of Mega Housing Projects}

The construction of mega housing projects faces several construction challenges which can greatly impact construction stakeholder's objectives in successfully delivering their mega housing projects. Mega-projects are classified in the highly complex program category facing numerous challenges and facing the most extreme project characteristics [2]. Table 3 and Table 4 presents mega housing projects construction challenges for developed and developing countries. Mega housing projects challenges are illustrated differently since the context differs regarding the country constructing mega housing projects. Mega housing projects challenges are further classified into either internal or external challenges. Internal challenges present the challenges induced within mega housing projects stakeholder's which can impact a mega project's budget cost and schedule.

Table 3. Challenges for construction of Mega housing projects in Developed Countries

\begin{tabular}{|c|c|c|c|}
\hline \multicolumn{4}{|c|}{$[3,16,17,18,19]$} \\
\hline Reference & $\begin{array}{l}\text { Case } \\
\text { Study }\end{array}$ & Challenges & C \\
\hline \multirow[b]{4}{*}{ Ina (2016) } & \multirow{3}{*}{$\begin{array}{l}\text { City of } \\
\text { Wien }\end{array}$} & Flexibility of Policy & $\mathrm{CE}$ \\
\hline & & Use of Resources & $\mathrm{CE}$ \\
\hline & & Resources Allocation & $\mathrm{Cl}$ \\
\hline & \multirow{3}{*}{$\begin{array}{l}\text { Waterf } \\
\text { ront }\end{array}$} & Talented Workforce & $\mathrm{Cl}$ \\
\hline \multirow{3}{*}{$\begin{array}{l}\text { Ning } \\
(2016)\end{array}$} & & Decentralized Sites & $\mathrm{Cl}$ \\
\hline & & formal and informal & \multirow{2}{*}{$\mathrm{Cl}$} \\
\hline & \multirow{3}{*}{$\begin{array}{c}\text { Europe } \\
\text { Smart } \\
\text { Mega } \\
\text { Cities }\end{array}$} & Governments & \\
\hline \multirow{2}{*}{$\begin{array}{l}\text { Rafaela et } \\
\text { al (2015) }\end{array}$} & & Economic Decline & $\mathrm{Cl}$ \\
\hline & & $\begin{array}{l}\text { Mono sectoral } \\
\text { Economy }\end{array}$ & CE \\
\hline \multirow{3}{*}{$\begin{array}{l}\text { Helfert } \\
(2015)\end{array}$} & \multirow{3}{*}{$\begin{array}{l}\text { China } \\
\text { Yinchu } \\
\text { an City }\end{array}$} & Safety and Security & $\mathrm{Cl}$ \\
\hline & & Lack of Data Base & $\mathrm{Cl}$ \\
\hline & & $\begin{array}{l}\text { Multicultural } \\
\text { Diversity }\end{array}$ & $\mathrm{Cl}$ \\
\hline \multirow{3}{*}{$\begin{array}{l}\text { Tablish et } \\
\text { al (2011) }\end{array}$} & \multirow{3}{*}{$\begin{array}{l}\text { Sydney } \\
\text { Opera } \\
\text { House }\end{array}$} & Talent Gap inside & $\mathrm{Cl}$ \\
\hline & & Organizations & 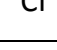 \\
\hline & & $\begin{array}{l}\text { Construction } \\
\text { Technology }\end{array}$ & $\mathrm{Cl}$ \\
\hline
\end{tabular}

External challenges include the external construction environment for stakeholders adding more mega housing projects challenges. The tables are classified into reference, publish date, country, classification of the challenge, and challenge codes. The challenges are thus coded either external or internal. CE presents external construction challenges and $\mathrm{Cl}$ presents internal construction challenges.

Table 4. Challenges of Mega housing projects in Developing Countries [15,16,20,21,22,23,24]

\begin{tabular}{|c|c|c|c|}
\hline Reference & Countries & Challenges & C \\
\hline \multirow{12}{*}{$\begin{array}{c}\text { Egyptian } \\
\text { Strategy } \\
2030 \\
\text { (2016) } \\
\text { Egypt } \\
\text { Mega } \\
\text { housing } \\
\text { projects } \\
\text { MEED } \\
\text { Conferenc } \\
\text { e (2015) } \\
\text { Helfert } \\
\text { (2015) } \\
\text { Atkins } \\
\text { (2015) } \\
\text { Othman } \\
\text { (2013) } \\
\text { Khorshed } \\
\text { (2017) }\end{array}$} & \multirow{3}{*}{$\begin{array}{c}\text { Egypt New } \\
\text { Capital } \\
\text { Mega } \\
\text { Housing } \\
\text { Project }\end{array}$} & $\begin{array}{c}\text { Government } \\
\text { Policy Flexibility }\end{array}$ & CE \\
\hline & & $\begin{array}{l}\text { Governance } \\
\text { Instability }\end{array}$ & CE \\
\hline & & $\begin{array}{c}\text { Economy } \\
\text { Weakness }\end{array}$ & CE \\
\hline & \multirow{2}{*}{$\begin{array}{c}\text { New Mega } \\
\text { Housing } \\
\text { Projects in } \\
\text { Africa }\end{array}$} & $\begin{array}{c}\text { Lack of } \\
\text { Competitiveness }\end{array}$ & CE \\
\hline & & $\begin{array}{l}\text { Resources } \\
\text { Scarcity }\end{array}$ & $\mathrm{Cl}$ \\
\hline & \multirow{4}{*}{$\begin{array}{c}\text { Mega } \\
\text { Housing } \\
\text { Projects in } \\
\text { Morocco }\end{array}$} & $\begin{array}{l}\text { Work Force } \\
\text { Diversity }\end{array}$ & $\mathrm{Cl}$ \\
\hline & & Innovation used & $\mathrm{Cl}$ \\
\hline & & Lack of Data Base & $\mathrm{Cl}$ \\
\hline & & Poor Training & $\mathrm{Cl}$ \\
\hline & \multirow{3}{*}{$\begin{array}{c}\text { Mega } \\
\text { Housing } \\
\text { Projects in } \\
\text { Tunisia }\end{array}$} & $\begin{array}{l}\text { Providing a long- } \\
\text { term HR Strategy }\end{array}$ & $\mathrm{Cl}$ \\
\hline & & Poor HR Skills & $\mathrm{Cl}$ \\
\hline & & Revolutions & CE \\
\hline
\end{tabular}

It is clear from the above studies presented in Table 4 and Table 5, that most developing countries agree on the major internal challenge facing stakeholders constructing mega housing projects is resource scarcity for construction of mega housing projects in developing countries. Mega housing projects construction requires a well-qualified and trained worker which is found to be scarce in developing countries. Most external challenges facing developing countries include security for construction workers, the poor technological workforce in supply from a country to a stakeholder, continues change of Governance systems and Poor Government commitment and transparency, Contractors are also not encouraging management of mega housing projects challenges. This is clear in challenges of week stakeholder policy and regulations.

However, there are joined challenges agreed between both developing and developed 
countries. Countries including all of Egypt, Pakistan, Atalanta, and China all agreed on providing the accurate database. More reliable database and information will fascinate the working conditions for mega housing projects employees and improve their productivity. Providing safe construction environment for workers is also one of the most important internal challenges in especially in Pakistan, Africa, and some European countries.

Despite there are noticeable mega housing projects construction challenges, but opportunities for both stakeholder's organizations and the country constructing the mega-project are noticed as well. Internal opportunities present the opportunities gained by stakeholder's organization after the construction of mega housing projects. External opportunities include opportunities which might benefit the country as a whole and this includes both tangible and intangible benefits to the community. Regarding developing countries, the most important opportunity gained from is providing job opportunities. Most countries suffer high unemployment rate which adds more pressure on communities and benefit construction of mega housing projects would offer.

\section{Review of Risk Management Studies}

Risk management process plays an important role in managing construction risks for megaprojects and locating uncertainties [25]. Table 5 presents a review of the process of risk management studies in order to identify construction projects risk factors and highlighting different categories impacting the successful delivery of construction projects. The process of risk management plays an important role in managing construction risks for megaprojects and locating uncertainties [25]. Risk management process is important in Mega housing projects, it is concluded that the best mega housing projects are those who can successfully manage construction risks efficiently [26]. Table 5 is classified into research, year, core area of the research, and identified categories and risks through each risk management research.
Table 5. A Review of Risk Management Studies

\begin{tabular}{|c|c|c|}
\hline Author & Study & Identified Risk Factors \\
\hline $\begin{array}{c}\text { Xiaohua et } \\
\text { al } \\
(2017)\end{array}$ & $\begin{array}{l}\text { correlation } \\
\text { between } \\
\text { stakeholder's } \\
\text { roles and risk } \\
\text { management } \\
\end{array}$ & $\begin{array}{l}\text { The researcher } \\
\text { studied factors } \\
\text { including power, } \\
\text { interest, and influence } \\
\text { [27] }\end{array}$ \\
\hline $\begin{array}{l}\text { Ghada } \\
\text { Farouk } \\
\text { (2016) }\end{array}$ & $\begin{array}{c}\text { Delay Causes } \\
\text { construction in } \\
\text { Egypt }\end{array}$ & $\begin{array}{l}\text { Owner Related } \\
\text { Consultant related, } \\
\text { Contractor related, \& } \\
\text { other groups [28] }\end{array}$ \\
\hline $\begin{array}{l}\text { El Kholy } \\
\text { (2015) }\end{array}$ & $\begin{array}{l}\text { Factors } \\
\text { impacting } \\
\text { construction } \\
\text { cost in Egypt } \\
\text { projects } \\
\end{array}$ & $\begin{array}{l}\text { Owner Financial, } \\
\text { contractor cash flow, } \\
\text { procurement method } \\
\text { [29] }\end{array}$ \\
\hline $\begin{array}{l}\text { Ojo et al } \\
\text { (2015) }\end{array}$ & $\begin{array}{l}\text { Risks impact on } \\
\text { construction } \\
\text { cost in Nigeria }\end{array}$ & $\begin{array}{l}\text { Bidding, project } \\
\text { characteristics, } \\
\text { estimating process, } \\
{[30]}\end{array}$ \\
\hline $\begin{array}{l}\text { Somya } \\
\text { (2014) }\end{array}$ & $\begin{array}{l}\text { Risks Impacting } \\
\text { Construction } \\
\text { Projects }\end{array}$ & $\begin{array}{l}\mathrm{PM} \text {, environment } \\
\text { risks, finance specific. } \\
\text { [31] }\end{array}$ \\
\hline $\begin{array}{l}\text { Othman } \\
\text { (2013) }\end{array}$ & $\begin{array}{l}\text { Success Factors } \\
\text { Megaprojects in } \\
\text { Developing } \\
\text { Countries }\end{array}$ & $\begin{array}{l}\text { Human development } \\
\text { challenge, managerial } \\
\text { challenge, political } \\
\text { challenge. [24] }\end{array}$ \\
\hline
\end{tabular}

It is concluded from the above risk management reviews that construction risk factors regarding most of the projects worldwide are categorized into internal and external risks. Internal risks include risks which occur internally within a mega project stakeholder's organization. This involves project related, owner related, consultant related, contractor related, subcontractor related, Labour related, contract related, Material related, Equipment related, financial risks. Reviews show that external risk factors are either identified and grouped into one group or further classified into financial risks, political risks, and environmental risks. Most of the risk management studies worked on identifying risk factors. Risk Researchers especially in the Egyptian context ensured that the database problem makes it hard for researchers and contractors to manage risks. Qualified workers, construction safety, and countries policies best highlight the main risks towards megaprojects. 


\section{Classification of Construction Risk Factors}

Figure 2 illustrates the risk register for risk factors concluded from different risk management studies. Risk factors are classified using risk break down structure (RBS).

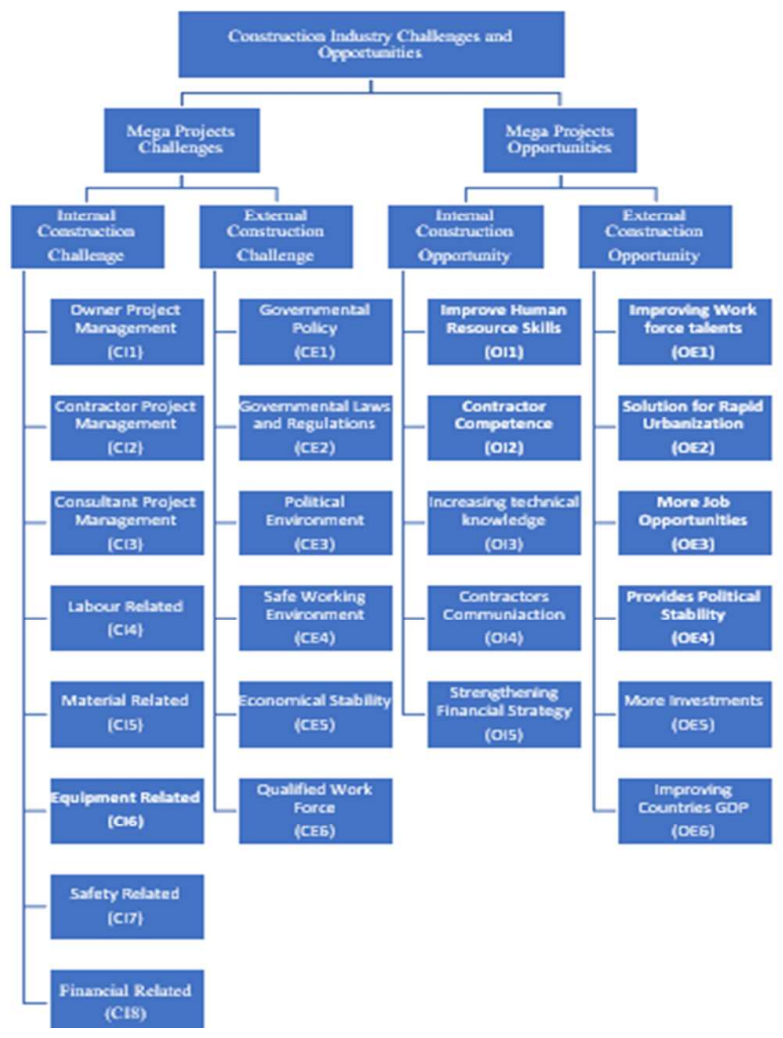

Figure 2. Identified Risk Factors Obtained from Risk Management Reviews.

$\mathrm{Cl}$ stands for internal challenges within an organisation constructing a mega project. CE presents external challenges within the country implementing the construction of mega housing projects. Despite these challenges are considered to be external, but they can impact the successful construction delivery of mega housing projects. OI is the internal opportunity which could benefit an organization from the construction of mega housing projects. At last, OE presents the external opportunity, which is the benefit a country could gain on implementing the construction of new mega housing projects. In other means, it includes the opportunities gained by the community.

\section{Analysis of Risks in Construction of Mega Housing Projects}

Figure 3 below illustrates prioritized challenges in the construction of mega housing projects in developed countries. Most of the case studies agreed that the highest challenge which has the greatest impact on mega housing projects construction time and budget is the contractor's project management roles $(\mathrm{Cl} 2)$. Where $18 \%$ of the mega housing projects studies agreed on contractors' success in managing mega housing projects resources. $14 \%$ of the mega housing projects studies realized that human resource challenges within stakeholder's organisations have a great impact on projects objectives. The third important challenge includes mega project owner project management $(\mathrm{Cl} 1)$ with $12 \%$ of mega housing projects case studies agree on it. Countries rules and regulations present the greatest impact on mega housing projects construction objectives. Despite governmental supportive policies is identified as a major challenge by some mega housing projects case studies, but it seems to be the least impact of all other challenges with just 3\% of mega housing projects agree on it.

Figure 4 below illustrates prioritized challenges in the construction of mega housing projects in developing countries. Most of the case studies agreed that the highest challenge which has the greatest impact on mega housing projects success in delivery is the contractors project management roles $(\mathrm{Cl} 2)$. Where $23 \%$ of the mega housing projects studies agreed on contractors' success in managing mega housing projects resources. It is realized that also the same challenge is the most agreed for mega housing projects construction within developed countries. $19 \%$ of the mega housing projects studies realized that human resource challenges within organisations $(\mathrm{Cl} 4)$ has a great impact matching also the second agreed on the challenge within developed countries. With $10 \%$ agreed on challenges, both organizations safety precautions $(\mathrm{Cl} 7)$ and flexibility of countries policies (CE1) share the same importance. Despite their importance but both qualified workforces (CE6) and poor economic environment for 
countries (CE5) is said to be the least agreed by mega housing projects case studies with $3 \%$ each.

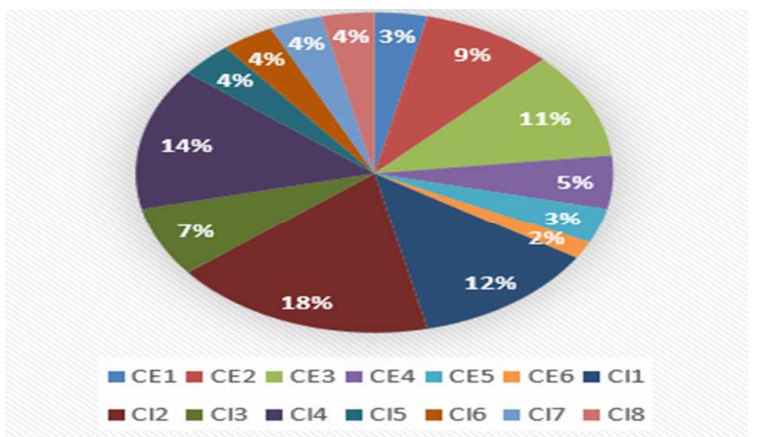

Figure 3. Challenges in construction of mega housing projects in developed countries.

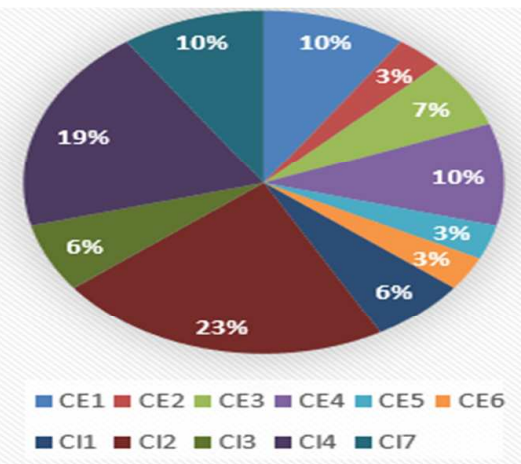

Figure 4. Challenges in construction of mega housing projects in developing countries.

\section{Lessons Learnt}

Most of the risk management researchers recommend the improvement of risk management practice knowledge. Especially for risk management studies carried in Egypt. Researchers ensure on the issue of weak governmental policies and transparency in identifying construction challenges for the contractors. Qualified workforce seems to be another issue. Stakeholders practising risk management based on an efficient risk management code of practice and a solid data platform. Most of the researchers emphasized the need to plan and track financial expenditures regularly and to ensure owner cooperate and support the cash flow frequently. Bank Loans seems to be an issue for large complex mega housing projects. Authors urge contractors to continuously upgrade and support employee's knowledge of modern technical equipment's and improve their skills. Construction failure also occurs due to poor communication and collaboration both within an organization and between all construction stakeholder's regarding construction challenges.

\section{Conclusion}

It is useful for contractors to benefit from mega housing projects construction challenges and opportunities identified from this research. By taking these factors into consideration prior commencement of construction, helps the contractor to easily prepare his risk plan accurately. It also provides the basis to manage mega housing projects challenges more efficiently. Contractors can hereby track these challenges during construction and add any risks to the identified paper risk register. Mega housing projects contractors can consider risks which match their context since the study works on developing and developed countries. Stakeholder's policymakers can realize the failure of mega housing projects due to weak policies and regulations. Furthermore, the study recognizes concerns regarding risk management knowledge which should be strengthened starting from the universities till risk practice within stakeholder's organizations.

\section{References}

[1] Bent Flyvbjerg, 2014, "What You Should Know about Megaprojects and Why: An Overview," Project Management Journal, vol. 45, no. 2, April-May, pp. 6-19, DOI: 10.1002/pmj.21409

[2] Kardes, I., A. Ozturk, S. T. Cavusgil, and E.Cavusgil. (2013). Managing Global Megaprojects: Complexity and Risk Management. International Business Review.

[3] Rafaela Alfalla-Luque, Ivana Burcar Dunović, (2015), 'Risks in the Front End of Mega housing projects', European cooperation in science and technology. 
[4] EY. (2014, December 16). EY- Spotlight on Oil and Gas megaprojects. Retrieved from EY Website: ey.com/oil and gas/capital projects.

[5] Liu, H-Y., Kobernus, M., Broday, D., Bartonova, A., (2014.) A conceptual approach to a citizens' observatorysupporting community-based environmental governance. Environmental Health 13:107.

[6] Vidal, L.-A., Marle, F., and Bouquet, J.-C, (2011). "Measuring project complexity using the Analytic Hierarchy 715 Process." International Journal of Project Management, 29(6), 718-727.

[7] Mendel Giezen, Luca Bertolini \& Willem Salet, (2014), 'Adaptive Capacity Within Mega Project: A Case Study on Planning and Decision-Making in the Face of Complexity', European Planning Studies, DOI: 10.1080/09654313.2014.916254.

[8] Bosch-Rekveldt, M., Jongkind, Y., Mooi, H., Bakker, H., and Verbraeck, A. (2011). 'Grasping project complexity in large engineering projects'. International Journal of Project Management, pp. 728-739, Vol. (29), Issue (6).

[9] Syed Azim, Andy Gale, Therese Lawlor-Wright, Richard Kirkham, Ali Khan, Mehmood Alam, (2010) "The importance of soft skills in complex projects", International Journal of Managing Projects in Business, Vol. 3 Issue: 3, pp.387-401.

[10] Van Marrewijk, A., S. R. Clegg, T. S. Pitsis, and M. Veenswijk, (2008). 'Managing Public-private Megaprojects: Paradoxes, Complexity, and Project Design', International Journal of Project Management, pp. 591-600., Vol. (26), Issue (6).

[11] De Bruijn, H., \& Leijten, M. (2008). Management characteristics of megaprojects. In Primus, H., Flyvbjerg, B., and van Wee, B. (Eds.), Decision making on megaprojects: Cost-benefit analysis,
Planning and Innovation (pp. 23-39). Cheltenham, UK; Edward Elgar Publishing

[12] Sesant, (2017), 'Mega housing projects to finally get underway', CAPE ARGUS

[13] Megan Van Wyngaardt, (2017), Engineering News - Ekurhuleni launches new R8.9bn housing settlement in Boksburg.

[14] Leanna Garfield (2017), Business Insider, 6 billion-dollar projects that will transform London by 2025 http://www.businessinsider.com/londonmegaprojects-that-will-transform-the-city2017-8

[15] Khorshed, Mirette \& Lawrence Vale, (2017), 'Cairo's new administrative capital Wedian City: lessons from the past and for the future', Massachusetts Institute of Technology

[16] M. Helfert et al. (Eds.): Smartgreens, and Vehits, (2015), CCIS 579, pp. 17-31, 2015.DOI: 10.1007/978-3-319-27753-0_2

[17] Ina Homeier, (2016), 'The Smart City of Wein' Municipal Department, Vienna City Administration 2nd edition 2016.

[18] Ning. (2016) YINCHUAN special report: smart cities, www.tmforum.org

[19] Tabish, S.Z.S., Jha, K. N., (2011), 'Identification and evaluation of success factors for public construction projects', Construction Management and Economics, pp. 809-823, Vol. 29, Issue (8).

[20] Egypt vision 2030, (2016), Sustainable development strategy: Egypt vision 2030. Retrieved from http://sdsegypt2030.com/?lang=en.

[21] MEED Egypt Mega housing projects Conference, 2015, Profiling an Investment Road Map in Egypt.

[22] Atkins, (2015), The Skills Deficit: Consequences and opportunities for UK Infrastructure.

[23] ILO. 2014p. Rules of the game: a brief introduction to International Labour Standards (Geneva) 
[24] Othman, (2013), 'Challenges of mega construction projects in developing countries', DOI 10.5592/otmcj.2013.1.10. pp. 730-746

[25] Lehtiranta, L. (2014) Risk Perceptions and Approaches in Multi-Organizations: A Research Review 2000-2012. International Journal of Project Management, 32, 640653.

[26] Greiman, V. A. (2013). Megaproject management: Lessons on risk and project management from the Big Dig. New Jersey, USA: John Wiley \& Sons, Inc.

[27] Xiaohua Jina,, Guomin Zhangb, Junxiao Liuc, Yingbin Fenga, Jian Zuod, (2017), Procedia Engineering, pp.314-320.

[28] Ghada, Badawi \& Nawawy, (2016), 'A Model for Evaluation of Delays in Construction Projects' International Journal of Innovative Research in Science, Engineering and Technology, Vol. 5, Issue 3.

[29] El Kholy, (2015), 'Predicting Cost Overrun in Construction Projects' International Journal of Construction Engineering and Management, Vol. 4, pp. 95-105.

[30] Ojo, Grace \& Odediran, Sunday. (2015), 'Significance of Construction Cost Estimating Risks in Nigeria', pp.1-8, Vol. 2.

[31] Sowmya Rao \& V. Srinivasa Raghavan, (2014), 'Construction Risk Identification and Assessment' Indian Journal of Applied Research, pp. 2248-5555, Vol. (4), Issue (5) 